\title{
A Potential Approach to Predict Wax Precipitation from Reservoir Core Analysis
}

\author{
G. Guéhénneux ${ }^{1}$, I. Kowalewski ${ }^{1 *}$, E. Béhar ${ }^{2}$, A.Y. Huc ${ }^{3}$ and V. Ruffier-Meray ${ }^{2}$ \\ 1 Institut français du pétrole, Geology and Geochemistry Division, 1 et 4, avenue de Bois-Préau, \\ 92852 Rueil-Malmaison Cedex - France \\ 2 Institut français du pétrole, Thermodynamic and Transfer Department, 1 et 4, avenue de Bois-Préau, \\ 92852 Rueil-Malmaison Cedex - France \\ 3 IFP School (ENSPM), 228-232, avenue Napoléon-Bonaparte, 92852 Rueil-Malmaison Cedex - France \\ e-mail: isabelle.kowalewski@ifp.fr \\ * Author to whom correspondence should be sent
}

\begin{abstract}
Résumé - Prévision du risque de dépôt de paraffines à partir de l'analyse de carottes réservoirs — La précipitation des paraffines est un problème récurrent en production pétrolière. Une détection tardive de la présence de paraffines dans l'huile en place dans le réservoir, même en très faible quantité, peut entraîner des problèmes de production coûteux (blocage complet des conduites de production et des installations de surface, mauvaise estimation de la réserve productible). Dans un contexte de réduction des coûts de production, cet article propose une méthode de prévision du risque de dépôt de paraffines à un stade précoce de caractérisation des réservoirs. Les hydrocarbures saturés (HCS) à haut poids moléculaire ont été quantifiés par chromatographie gazeuse capillaire à haute température (GCHT) sur des fractions saturées d'huiles produites et d'extraits de roche correspondants.
\end{abstract}

Dans cette étude, deux échantillons d'huile ainsi que les carottes réservoirs associées provenant de deux champs adjacents, mais non communiquants, ont été considérés. Un des champs (champ P) présente des problèmes de précipitation de paraffines tandis que le second (champ $\mathrm{A}$ ) en est exempt. Après quantification des HCS à haut poids moléculaire, les résultats indiquent que l'extrait de carotte du champ $\mathrm{P}$ est enrichi en composés lourds (gamme de carbones : $\mathrm{C}_{14}-\mathrm{C}_{71}$ ) par rapport à l'huile produite (gamme de carbones : $\mathrm{C}_{14}{ }^{-} \mathrm{C}_{56}$ ), tandis que pour le champ A, qui ne présente pas de problème de production, les différences sont moins marquées, et surtout, la gamme de carbones est plus étroite $\left(\mathrm{C}_{14}-\mathrm{C}_{48}\right.$ pour l'huile produite et $\mathrm{C}_{14}-\mathrm{C}_{55}$ pour l'extrait de roche correspondant). Ces résultats montrent que les champs à risques pourraient être identifiés à un stade précoce de caractérisation des réservoirs, à savoir, dès qu'un échantillon de carotte est disponible.

De plus, ces données supplémentaires sur la distribution des HCS à haut poids moléculaire dans les carottes réservoirs pourront être ultérieurement utilisées dans les modèles de thermodynamique couramment mis en œuvre pour l'estimation de la quantité de paraffines précipitant dans les pipelines pendant le transport des fluides, afin de prédire, à un stade précoce de caractérisation d'un réservoir, le risque de dépôt de paraffines au sein du réservoir et dans les tubings lors de la mise en production. Des résultats préliminaires de modélisation, obtenus à partir de l'huile produite et de l'extrait de carotte du réservoir du champ $\mathrm{P}$, montrent que la température de cristallisation commençante des paraffines est 
sous-estimée si le calcul est réalisé avec les analyses de l'huile de stockage $\left(42^{\circ} \mathrm{C}\right)$ obtenue après mise en production du puits (ses paraffines se sont déjà déposées). Par contre, ce risque de dépôt aurait pu être anticipé avant le démarrage de la production, si la prévision avait été réalisée à partir des analyses de l'extrait d'un échantillon de carotte $\left(52^{\circ} \mathrm{C}\right)$.

\begin{abstract}
A Potential Approach to Predict Wax Precipitation from Reservoir Core Analysis - In the context of reducing production costs for the oil industry, this paper aims to suggest a way for predicting wax precipitation at an early stage of the reservoir characterization and production process. In this respect, reservoir core extracts and production oil-saturated fractions have been herein analyzed by high temperature gas chromatography $(H T G C)$ in order to quantify the high molecular weight hydrocarbons $(H M W H C)$ which are at the origin of wax deposits in the tubing and surface facilities.

Samples of oils and associated reservoir cores from two adjacent but non-communicating fields are considered in this paper. Wax deposition is documented for Field P but not for Field A. It is demonstrated that the reservoir core extract of Field $P$ is substantially enriched in HMWHC when compared to the produced oil, whereas for Field A, with no production problems, both profiles (oil and reservoir core extracts) are similar and depleted in HMWHC. These results suggest that fields exhibiting a risk of wax precipitation could be identified during the exploration phase as soon as reservoir cores are available.

Moreover, it can be envisioned that such additional data provided by the saturates distribution can potentially be used in future thermodynamic models (derived from those currently applied for assessing wax precipitation in pipelines during the transport of produced oil) in order to quantitatively predict, at an early stage of reservoir characterization, paraffins precipitation in reservoirs and tubings during production.

The preliminary computed results obtained for the produced oil and the reservoir rock extract of Field $P$ indicate that the temperature of paraffin crystallization onset is significantly under-estimated when using the composition of tank oil $\left(42^{\circ} \mathrm{C}\right)$ - heavy paraffins are already deposited. On the other hand, the predictive calculation, using the core extract $\left(52^{\circ} \mathrm{C}\right)$ and which can be performed as soon as a core sample is available, will allow us to minimize the risk of paraffin deposition during production and transportation.
\end{abstract}

\section{ABBREVIATIONS}

$\begin{array}{ll}\text { DCM } & \text { Dichloromethane } \\ \text { FID } & \text { Flame Ionization Detector } \\ \text { GC } & \text { Gas Chromatography }\end{array}$

HMWHC High Molecular Weight Hydrocarbons

HTGC High Temperature Gas Chromatography

PVT Pressure-Volume-Temperature

WAT Wax Appearance Temperature.

\section{INTRODUCTION}

Heavy wax precipitation is a recurrent problem in petroleum production. The resulting deposits, which are formed either in the tubing or within the reservoir itself, can generate a pressure drop at the wellhead which drastically affects the fluid withdrawal rate and defers production (Carnahan, 1989). Crystallization of these compounds results mainly from the cooling that is likely to occur during migration of oil in the subsurface or on its way from the reservoir to the surface. The degassing induced by the pressure drop that occurs when the fluid is produced also enhances paraffin deposition by removing the light components which act as a very effective solvent for high molecular weight hydrocarbons (HMWHC) (Ruffier-Meray et al., 1993).

Despite the importance of problems caused by heavy waxes, their study has been overlooked during many years because of the lack of analytical methods and because of the low concentration of HMWHC in oils collected at the wellhead (Del Rio et al., 1992; Philp, 1994; Thanh et al., 1999). The recent advent of high temperature gas chromatography (HTGC) allows rapid characterization and quantification of individual compounds up to $\mathrm{C}_{100}$ in oils and rock extracts (Philp et al., 1995). Several applications in petroleum exploration and production result from this analytical improvement. Carlson et al. (1993) have shown that the profile of some specific compounds in the $\mathrm{C}_{40+}$ fraction seems to be dependent on the source rock organic facies and therefore can be used to perform oil/oil and oil/source rock correlations. Moreover HMWHC seem to be resistant to biodegradation (Heath et al., 1997) implying that 
these compounds allow the extension of oil/source rocks and oil/oil correlations even when considering strongly altered fluids.

But the main concern for the petroleum industry, as far as HMWHC are concerned, regards the prediction of their deposition in field facilities (Ferworm, 1997; Thanh et al., 1999). Thermodynamic models have been developed to predict wax precipitation that occurs during the oil transport in pipelines (Weingarten and Euchner, 1988; Calange, 1996; Calange et al., 1997) but these models are not directly applicable to wax precipitation during production because the input parameters used by these models are deduced from the produced oil which has lost, if precipitation has already occurred, most of the $\mathrm{C}_{40+}$ fraction either within the reservoir or along the tubing. Consequently no clues are currently available to assess the risk associated with paraffins precipitation in the reservoir and tubing. Moreover, as the onset of wax precipitation depends strongly on the alkanes exhibiting the longest chain length in the fluid, information on the $\mathrm{C}_{40+}$ composition within the reservoir is of paramount importance in order to predict wax deposition in production facilities. Consequently, the HMWHC $\left(>\mathrm{C}_{40}\right)$ should be characterized precisely from both analytical and thermodynamic points of view in a model still to be proposed (if possible as pure components). However as light fraction $\left(\mathrm{C}_{14}\right)$ cannot be analyzed reliably in core samples, its characterization should be obtained from independent data (well data for example).
A new manner addressing the prediction of wax precipitation in wells is proposed. Accounting for the fact that the oil collected at the wellhead is not an aliquot of the fluid actually in place within the reservoir, the comparison of the composition of the produced fluid and of the reservoir rock extract should provide valuable information on the phenomena affecting the oil as a result of its transport within the reservoir or during its transit to the surface. This paper presents an approach based on the analysis of the $\mathrm{C}_{40+}$ hydrocarbons distribution in reservoir rock extracts and on its comparison with the hydrocarbon composition of the associated production oils.

\section{MATERIALS AND METHOD}

In the present work, HMWHC distribution in production oil and in the associated reservoir core extract has been compared for two adjacent but not communicating fields (A and $\mathrm{P}$ ). These two fields are alleged to be fed by the same regional source rock, as there is only one mature source rock in the area. The two fields, separated by a fault, belong to the same formation, but Field A produces from $3050 \mathrm{~m}$ whereas Field P produces from $3850 \mathrm{~m}$. This difference in depth results in a noticeable difference in temperature (respectively $90^{\circ} \mathrm{C}$ for Field A and $115^{\circ} \mathrm{C}$ for Field P). Reservoir rock samples have been grounded and extracted following a sequential approach comparable to already published
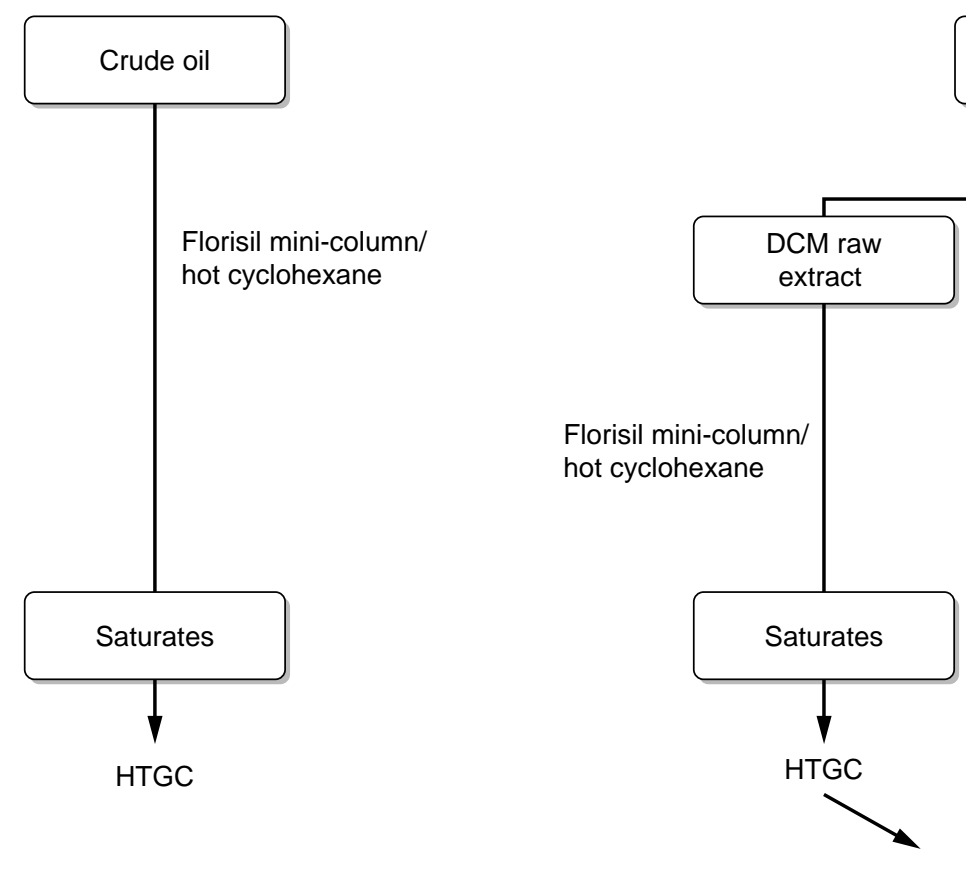

Figure 1

Flow chart of the analytical procedure. 
procedures (Mueller and Philp, 1998). The first step is an extraction performed in a round bottom flask using dichloromethane $(\mathrm{DCM})$ at reflux $\left(40^{\circ} \mathrm{C}\right)$ during one hour (the ratio rock/DCM is taken as 1/10). The second step is the extraction of the resulting residual rock under the same conditions but using cyclohexane (the ratio rock/cyclohexane is taken as 1/10). Cyclohexane is used for its efficiency to dissolve $\mathrm{HMWHC}$, its high boiling point $(\mathrm{BP})=80^{\circ} \mathrm{C}$ and because it is easier to evaporate when compared to aromatics such as $p$-xylene $\left(\mathrm{bp}=138^{\circ} \mathrm{C}\right)$ commonly used in the literature (Philp et al., 1995). After each extraction step, extracts are recovered by filtration under vacuum, while the solvent is still hot $\left(>50^{\circ} \mathrm{C}\right)$, followed by the solvent evaporation using a rotary evaporator. The critical factor in the isolation of HMWHC is the temperature of the solvents (for extraction as well as for filtration) which needs to be accurately maintained at the designated values.

The saturates fraction is obtained from oil and rock extracts by separation on Florisil ${ }^{\odot}$ (Merck, ref. 12519). A Pasteur pipette used as a mini-column is filled with $6 \mathrm{~cm}$ of Florisil $^{\circledR}$; $20 \mathrm{mg}$ of sample diluted in a minimum of cyclohexane are deposited at the column head and eluted with $5 \mathrm{ml}$ of hot cyclohexane $\left(\mathrm{T}\right.$ around $\left.50^{\circ} \mathrm{C}\right)($ Fig. 1). The saturates fraction is subsequently analyzed by HTGC (Varian 3800). One $\mu$ l solution of the sample in hot cyclohexane at a concentration of $2 \mathrm{mg} / \mathrm{ml}$ is injected on a J\&W DB1HT capillary column (length: $30 \mathrm{~m}$, int. diameter: $0.32 \mu \mathrm{m}$, film thickness: $0.1 \mu \mathrm{m})$. The injector temperature is programmed from $50^{\circ}$ to $230^{\circ} \mathrm{C}$ at $20^{\circ} \mathrm{C} / \mathrm{min}$ and from $230^{\circ}$ to $380^{\circ} \mathrm{C}$ at $5^{\circ} \mathrm{C} / \mathrm{min}$ with a final isotherm during $31 \mathrm{~min}$ (splitless mode). The column oven is programmed as follows: $50^{\circ} \mathrm{C}$ during $1 \mathrm{~min}$, then from $50^{\circ}$ to $230^{\circ} \mathrm{C}$ at $10^{\circ} \mathrm{C} / \mathrm{min}$, from $230^{\circ}$ to $370^{\circ} \mathrm{C}$ at $5^{\circ} \mathrm{C} / \mathrm{min}$ with a final isotherm during $20 \mathrm{~min}$. The FID is set at $400^{\circ} \mathrm{C}$ and helium is used as carrier gas at a constant column head pressure of 15 psi. The HMWHC isolation is repeated and the method is reproducible.

As there are two extracts for each reservoir rock (corresponding either to DCM or cyclohexane extraction), there are two resulting HTGC profiles (Figs. $2 a$ and $2 b$ ). In order to reconstruct the whole saturates distribution on a synthetic GC trace, the two initial gas chromatograms are combined on the basis of the individual $n$-alkanes content (in the range $\mathrm{C}_{40}$ to $\left.\mathrm{C}_{60}\right)$. These are quantified by addition of an internal standard (squalane) introduced in the extracts, and accounting for the relative amount of both extracts.
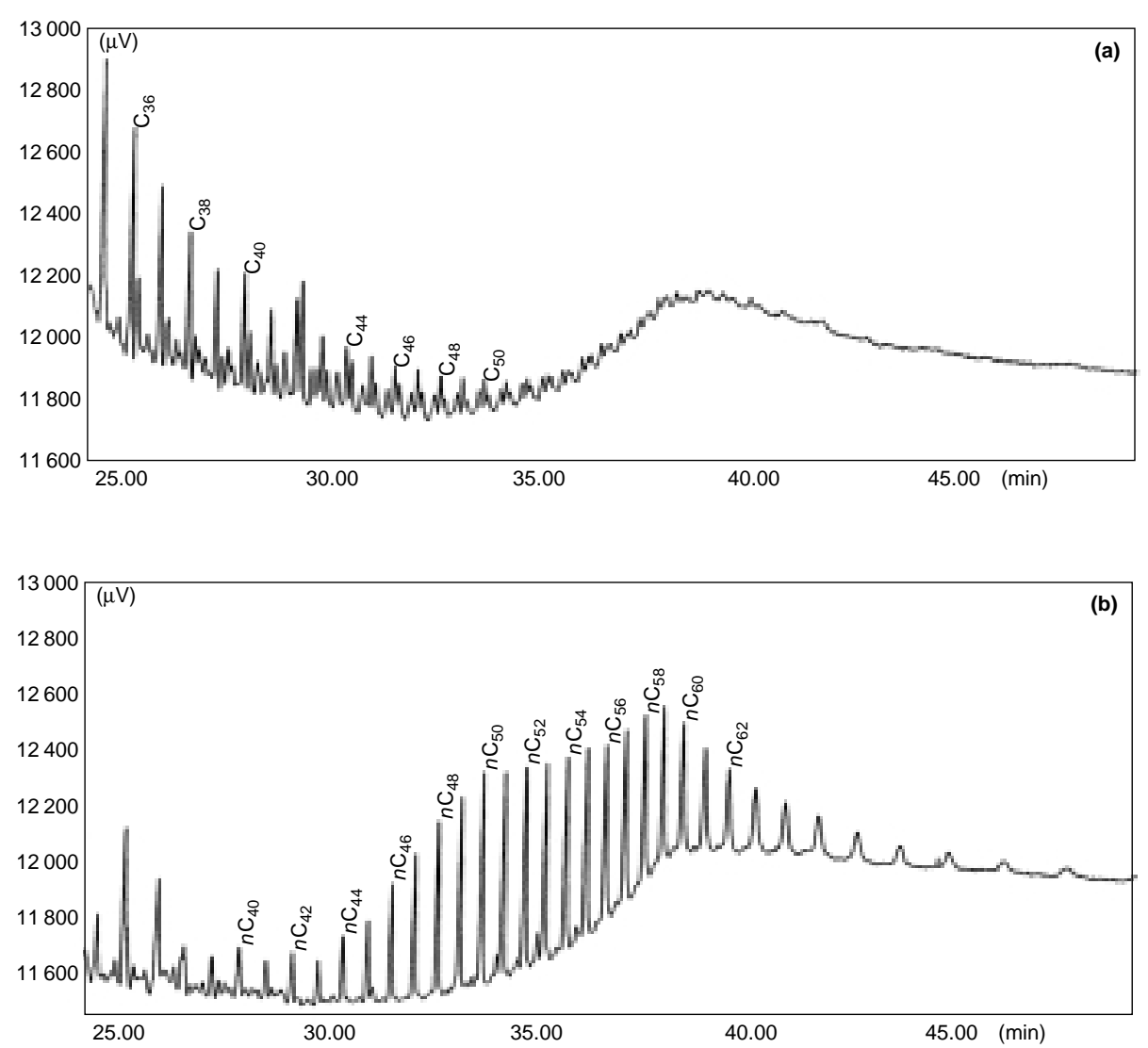

Figure 2

HTGC chromatograms of the $\mathrm{C}_{35+}$ saturates provided by the first DCM rock extraction (a) and by the second cyclohexane rock extraction (b). 


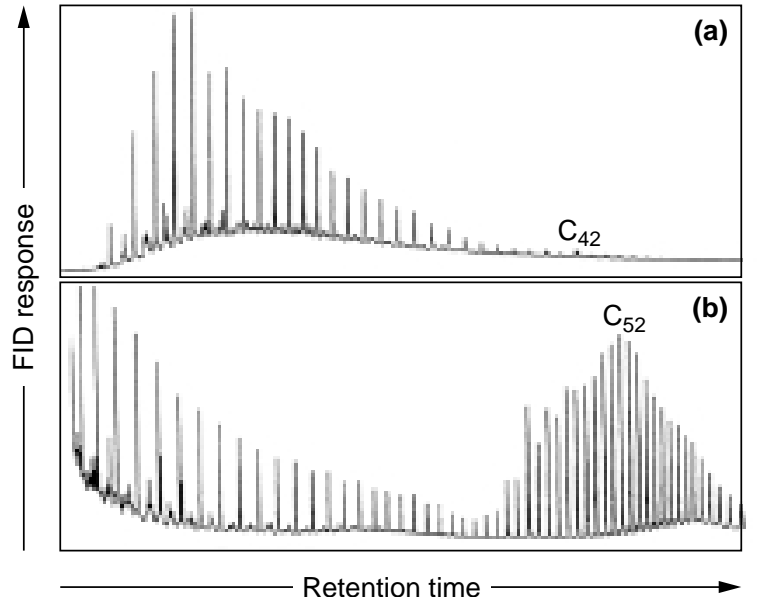

Figure 3

HTGC chromatograms of Field P produced oil (a) and its associated separator wax deposit (b).

\section{RESULTS AND DISCUSSION}

\subsection{Experimental Results}

For the two fields studied (A and P), only one is affected by wax precipitation (Field P), the other (Field A) being free of any production problem. Figures $3 \mathrm{a}$ and $3 \mathrm{~b}$ show the HTGC saturates profile of produced oil and of its associated paraffins deposit recovered in the separator of Field P. Despite the fact that HMWHC are detectable in the saturates fraction of the produced oil $\mathrm{P}$, their relative content is very low when compared to the associated paraffins deposit which has a prominent second mode in the $\mathrm{C}_{52}$ range. The presence of such a deposit suggests that the produced oil might have lost a substantial amount of its initial content in HMWHC between the reservoir and the outlet of the separator. In this respect, the composition of the oil sampled at the outlet of the separator cannot be a relevant input data for thermodynamic models in order to predict the behavior of this hydrocarbon fluid in the reservoir and in the well during production. (a)

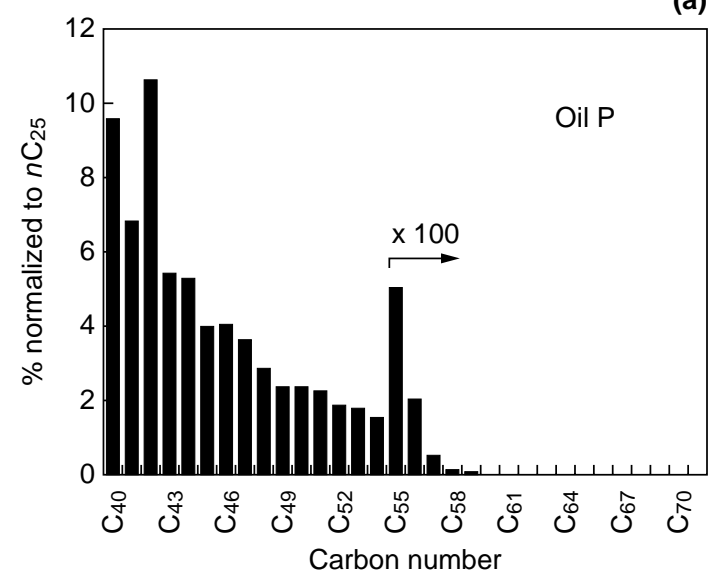

(c)

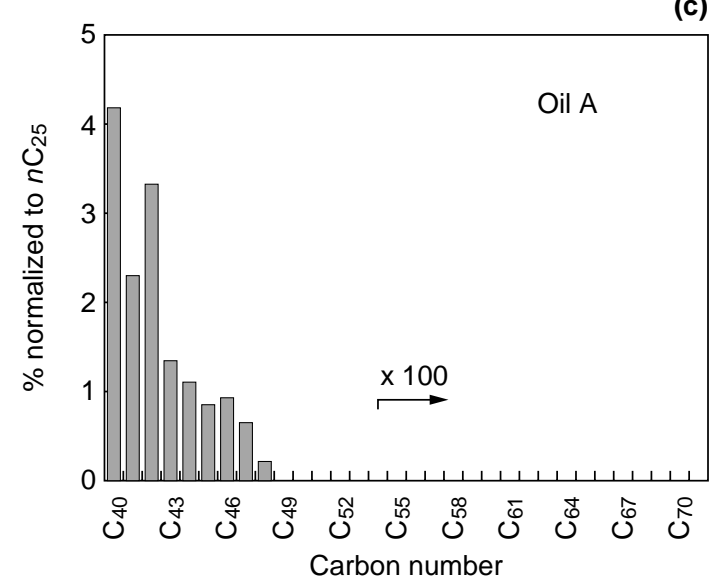

(b)

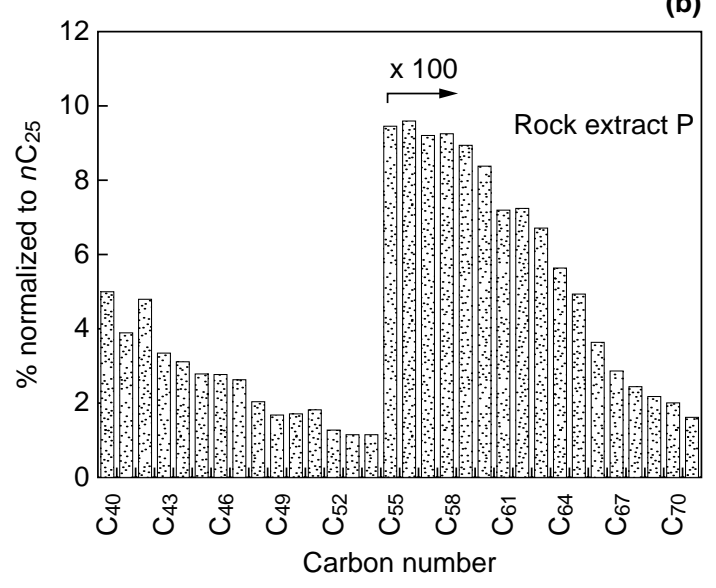

(d)

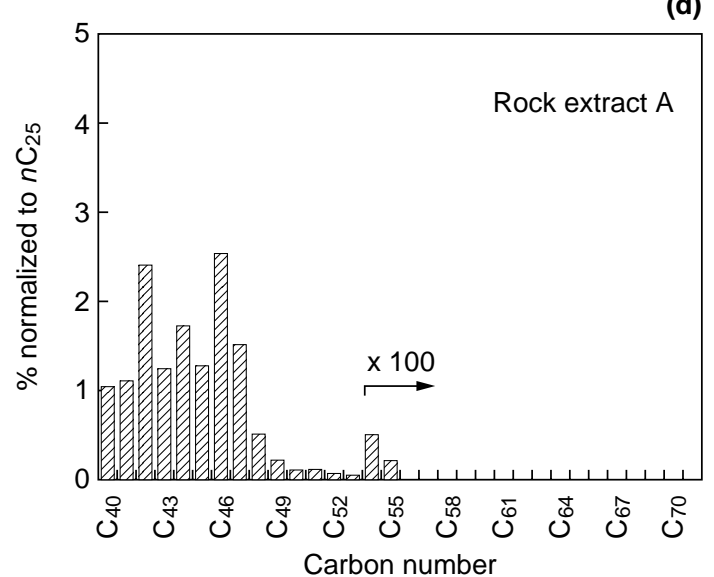

Figure 4

High molecular weight hydrocarbon distribution in Fields P and A production oils and in their associated reservoir core extracts. 
Figure 4 shows the $\mathrm{C}_{40+}$ saturates profile (normalized to $n \mathrm{C}_{25}$ ) of the produced oils and their associated rock extracts for the two studied fields. For Field A, with no production problem, the $\mathrm{C}_{40+}$ profile of the oil seems to be relatively similar to the $\mathrm{C}_{40+}$ profile of the reservoir rock extract; the reservoir rock extract is just slightly relatively enriched in HMWHC. The GC trace of the saturates obtained from the rock extract extends up to $\mathrm{C}_{55}$ whereas the $\mathrm{GC}$ trace of the saturates obtained from the oil only reaches $\mathrm{C}_{48}$. In Field $\mathrm{P}$, GC saturates profiles, for the reservoir rock extract and for the produced oil, are dramatically different. The $\mathrm{C}_{40+}$ hydrocarbons in the reservoir rock are much more abundant than in the produced oil. The HMWHC distribution decreases for the oil starting from $\mathrm{C}_{44}$ and extends up to $\mathrm{C}_{56}$, while the $n$-alkanes profile for the reservoir extract extends up to $\mathrm{C}_{70}$ (a feature that can be recognized in the wax deposited in the separator, Fig. 3). The "missing" compounds in the oil profile are probably related to the HMWHC which have precipitated in the tubing and surface facilities and which are subsequently absent in the oil flowing from the separator outlet.

The difference in wax content between the two rock extracts of the considered fields is compatible with their

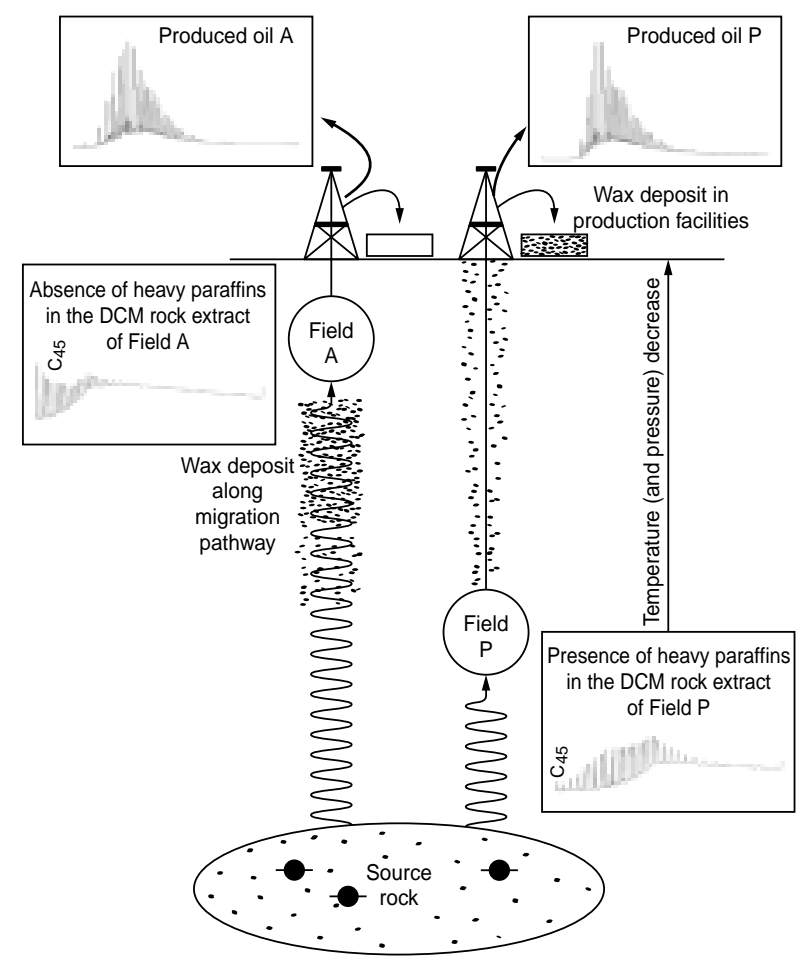

Figure 5

Schematic model proposed for the difference in wax content between Fields A and P. different depths and therefore with their different temperatures $\left(90^{\circ} \mathrm{C}\right.$ for Field $\mathrm{A}$ and $115^{\circ} \mathrm{C}$ for Field $\left.\mathrm{P}\right)$ as explained in Figure 5. The fact that the onset temperature of $\mathrm{C}_{60}$ and $\mathrm{C}_{50}$ crystallization is set respectively at $99^{\circ}$ and $92^{\circ} \mathrm{C}$ (Callange, 1996) is in good agreement with this hypothesis. In this respect it can be inferred that the oil released by the common source rock contains a high content of HMWHC which is reflected in the composition of the oil pooled (reservoir rock extracts) in the hotter Field P. The subordinate content of HMWHC in the oil pooled in Field A (reservoir rock extracts) can be tentatively explained by a loss of these compounds as they experience a decrease of temperature along the migration pathway from the source rock to the cooler Field A. These results illustrate that wax precipitation does not only depend on changes in PVT conditions as the fluid is brought to the surface (i.e. decrease in temperature and pressure) but also on the initial wax content of the fluid actually flowing within the reservoir and reaching the tubing.

\subsection{Thermodynamical Model}

\subsubsection{Theoretical Aspects}

This approach provides a qualitative means to assess the occurrence of a wax deposition risk. However the ultimate goal of this type of analysis is obviously to provide a relevant input to be used in a thermodynamic model designed to quantitatively predict the risk of paraffin deposition in the reservoir as well as in the tubing and surface facilities. Such a model, which still needs to be adapted for this purpose, has to account for:

- the transport of waxes within the reservoir;

- the deposition of waxes during transport in the well, from the reservoir to the surface facilities.

The first step of such a modeling approach should be to determine the quantity of immobile, and consequently of mobile paraffins, at reservoir temperature and pressure conditions. The currently available thermodynamic models which can be used for this purpose, and which have been initially designed to describe wax precipitation in pipelines, are compositional. They account for an analytical description of a considered produced oil including: dissolved gas, $\mathrm{C}_{20-}$ versus $\mathrm{C}_{20+}$ balance obtained by flash distillation of stock tank oil, molecular quantification of the $\mathrm{C}_{20-}$ fraction components, analysis of the $\mathrm{C}_{20+}$ fraction in terms of $n$-paraffins, iso-paraffins, cyclo-paraffins, resins and asphaltenes. This description is ultimately transformed into an optimized, limited set of pseudo-components associated with actual thermodynamic properties such as molecular weight, melting temperature, enthalpy of melting, solid-solid transition temperature, critical pressure and temperature, acentric factor and Rackett compressibility factor (Calange et al., 1997). 
To be applicable to the specific problem of "in-reservoir" waxes, this type of model has to be adapted to account for:

- the occurrence of high molecular weight paraffins, described in production deposits or in source rocks and reservoir rocks and which have been largely lost when considering wellhead oils;

- the contrasted behavior of the different compounds constituting this heavy waxy fraction. For instance, only $n$-paraffins lead to a crystalline deposit, while all the other components (iso- and cyclo-alkanes) are trapped as an amorphous gel (Dirand et al., 1998);

- a less detailed characterization of the light fraction $\left(\mathrm{C}_{14}\right)$ which is not available in the reservoir exploration phase.

Moreover the thermodynamic parameters, which are available in databases for low and, to a lesser extent, intermediate molecular weight molecules, have to be determined by extrapolation for the higher molecular weight molecules. Such an extrapolation has proved to be reasonable for heavy $n$-alkanes (Calange, 1996), but no data are available for the iso- and cyclo-alkanes because there is a lack of available pure components, in the intermediate molecular weight range, to obtain any direct determination of thermodynamic data. Consequently, for these compounds, any extrapolation becomes problematic.

In this respect the current thermodynamic models are probably well fitted to compute the behavior of systems rich in $n$-alkanes but not adapted for systems in which iso- and cyclo-alkanes become an important fraction. Although their presence induces the amorphous gel occurrence rather than crystalline deposit, their thermodynamic parameters are needed for any numerical simulations in order to calculate the onset crystallization temperature of a fluid.

The second step of a modeling approach, designed to be predictive for the risk of wax deposition in wells and surface facilities, will require to couple this adapted thermodynamic model with an existing multiphase fluid flow model describing the crude hydrodynamics while rising in the well and flowing in the facilities. In such a model, multiphase thermodynamic flash calculations are performed, in a 1D grid (representing the well) at different pressure and temperature steps, in order to predict along the flow pathway the possible existence of gas, oil and solid waxy phases and to compute the quantity of each of them.

\subsubsection{Numerical Simulation}

However, a numerical simulation was tentatively applied on the produced oil and the extract of the corresponding reservoir core of Field $\mathrm{P}$ using the thermodynamic model, currently applied for assessing wax precipitation in pipelines during production. This model (Calange, 1996; Calange et al., 1997) is based on the Peng-Robinson equation of state (Peng and Robinson, 1976) linked with the groups contribution model proposed by Abdoul et al. (1991). The produced oil was described as defined by Calange (1996) with nine pseudo-components, five for the $\mathrm{C}_{14}$ fraction and four for the $\mathrm{C}_{14+}$. The rock extract was characterized in a first attempt using 26 pseudo-components as described hereafter. Indeed the $\mathrm{C}_{14-}$ concentration was set to zero and the $\mathrm{C}_{14+}$ fraction was represented by five pseudo-components between $\mathrm{C}_{14}$ and $\mathrm{C}_{40}$ (as described by Calange) and all the normal paraffins between $\mathrm{C}_{40}$ and $\mathrm{C}_{60}$. For simplification the $\mathrm{C}_{60} n$-alkane represents all the normal paraffins heavier than $\mathrm{C}_{60}$. In addition, no heavy iso- nor cyclo-paraffins could be taken into account because thermodynamic parameters are not documented in the standard database of pure compounds. The representation of the fluid by 26 compounds is given in Table 1. According to this numerical approach, the preliminary results obtained for the produced oil and the reservoir rock extract of Field $\mathrm{P}$ indicate that the onset temperature of paraffin crystallization $\left(42^{\circ} \mathrm{C}+/-2^{\circ} \mathrm{C}\right)$ is under-estimated when using the composition of tank oil by comparison to the value obtained when using the reservoir rock extract composition $\left(52^{\circ} \mathrm{C}+/-2^{\circ} \mathrm{C}\right)($ Fig. 6). The difference between the wax appearance temperature (WAT) for the produced oil sample and the reservoir rock extract is $10^{\circ} \mathrm{C}$. This points out that heavy paraffins have been already deposited during production and that a predictive calculation using the core extract as soon as a core sample is available will allow to optimize the risk of paraffins deposition during production and transportation.

TABLE 1

Representation of the wax deposit for thermodynamic modeling

\begin{tabular}{|c|c|}
\hline Pseudo-component & Molar (\%) \\
\hline$n$-paraffins $\left(n \mathrm{C}_{15}-n \mathrm{C}_{17}-n \mathrm{C}_{19}\right)$ & 20.45 \\
\hline$n$-paraffins $\left(n \mathrm{C}_{14}-n \mathrm{C}_{16}-n \mathrm{C}_{18}-n \mathrm{C}_{20}\right)$ & 22.03 \\
\hline Iso/cycloparaffins $(20<n \mathrm{C}<40)$ & 12.4 \\
\hline Aromatic compounds $\left(\mathrm{C}_{20-}\right)$ & 28.1 \\
\hline Pseudo $1 n$-paraffins $(20<n \mathrm{C}<27)$ & 13.9 \\
\hline Pseudo $2 n$-paraffins $(27<n \mathrm{C}<40)$ & 2.95 \\
\hline$n \mathrm{C}_{41}$ & 0.016 \\
\hline$n \mathrm{C}_{42}$ & 0.045 \\
\hline$n \mathrm{C}_{43}$ & 0.012 \\
\hline$n \mathrm{C}_{44}$ & 0.016 \\
\hline$n \mathrm{C}_{45}$ & 0.013 \\
\hline$n \mathrm{C}_{46}$ & 0.013 \\
\hline$n \mathrm{C}_{47}$ & 0.014 \\
\hline$n \mathrm{C}_{48}$ & 0.014 \\
\hline$n \mathrm{C}_{49}$ & 0.009 \\
\hline$n \mathrm{C}_{50}$ & 0.015 \\
\hline$n \mathrm{C}_{51}$ & 0.026 \\
\hline$n \mathrm{C}_{52}$ & 0.014 \\
\hline$n \mathrm{C}_{53}$ & 0.015 \\
\hline$n \mathrm{C}_{54}$ & 0.003 \\
\hline$n \mathrm{C}_{55}$ & 0.0028 \\
\hline$n \mathrm{C}_{56}$ & 0.0027 \\
\hline$n \mathrm{C}_{57}$ & 0.0027 \\
\hline$n \mathrm{C}_{58}$ & 0.0027 \\
\hline$n \mathrm{C}_{59+}$ & 0.0024 \\
\hline
\end{tabular}




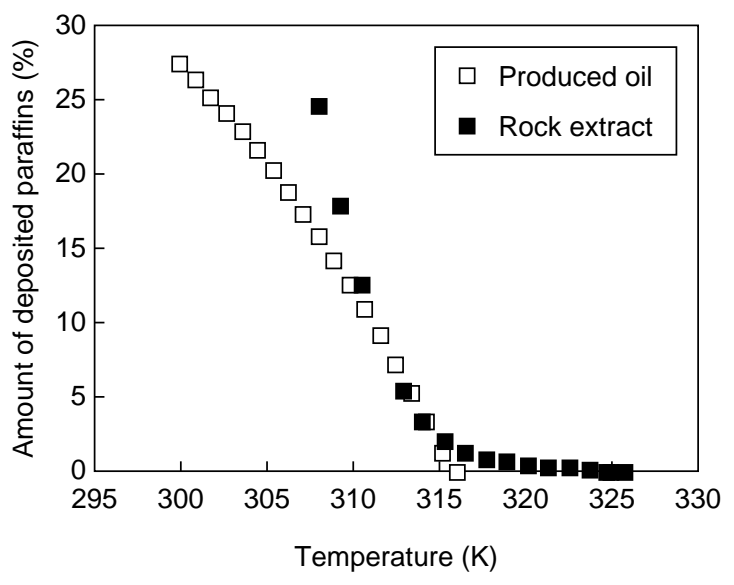

Figure 6

Comparison of the computed amounts of paraffins deposit obtained using the composition of the produced oil and of the rock extract for Field P.

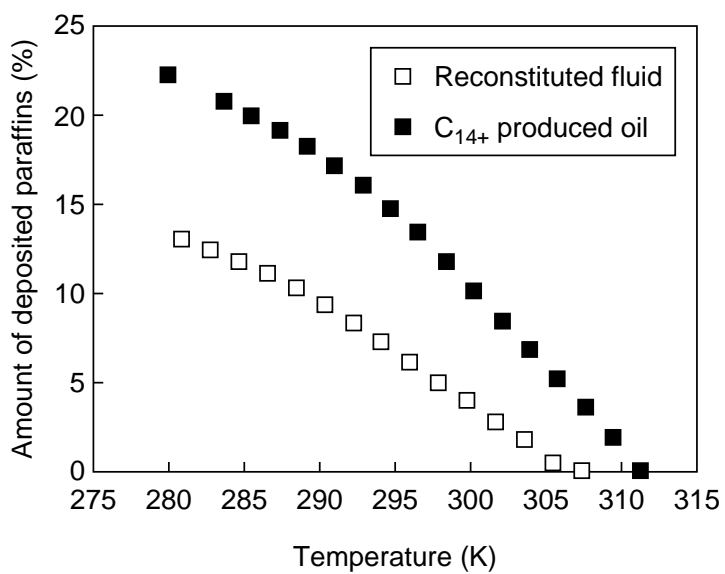

Figure 7

Influence of the light fraction $\left(\mathrm{C}_{1}-\mathrm{C}_{13}\right)$ on the computed onset crystallisation temperature of Field $\mathrm{P}$ paraffins.
Moreover the light fraction of the fluid is known to act as a good solvent for high molecular weight paraffins (RuffierMeray et al., 1993). Therefore the influence of the light fraction on the WAT was studied using a sample originating from another area and for which the composition of the total fluid $\left(\mathrm{C}_{14_{-}}\right.$and $\left.\mathrm{C}_{14_{+}}\right)$was known. The results are displayed in Figure 7 and show that in this case, the computed crystallization temperatures are determined with an uncertainty slightly higher than $5^{\circ} \mathrm{C}$, if the light fraction composition is not taken into account.

\section{CONCLUSIONS}

Wax precipitation risks can potentially be predicted at an early stage of field appraisal as soon as cores from the reservoir interval are available for geochemical analysis. The occurrence of a second mode within the $\mathrm{C}_{40+}$ region in the HTGC trace of the saturates from the core extract is a strong indication for a paraffins precipitation risk.

In a later step, the characterization of the HTGC profile of the produced oil saturates when compared to the reservoir core extract should allow to rapidly recognize the occurrence of an effective wax precipitation under the operating well conditions. This method would allow the operator to be aware of the paraffins deposition risk well in advance of any effective plugging of the production facilities.

Ultimately, this new information regarding the saturates distribution of the fluid within the reservoir can be used as an input to thermodynamic models derived from those available for computing wax precipitation during oil transport in pipelines (Weingarten and Euchner, 1988; Calange, 1996; Calange et al., 1997) and which are currently based on produced crude oil analytical data. The use of reservoir core data would allow us to conform these models to the assessment of the paraffins deposition risk during production both within the reservoir and along the tubing, by adapting the analytical representation of the fluid and the subsequent set of pseudo-components in order to account for the composition of the heavy alkanes fraction as confirmed by our preliminary numerical results.

The HMWHC, which are present in a given reservoir, are assumed to be in a mobile form because they have already migrated from the source rock to the reservoir. However the subsequent geological history of the reservoir has to be carefully considered because it might have induced changes in the conditions of the reservoir from its charging time up to the present day (i.e. cooling of the reservoir due to change in heat flow or uplifting, or loss of a part of the gas phase). In this respect, the total content and distribution of HMWHC in the reservoir may not be representative of the waxes which are effectively released together with the fluid mobilized within the reservoir. As a consequence, this approach still needs to be refined in order to qualitatively and quantitatively assess the HMWHC which are actually mobilized according to reservoir conditions. This goal can be achieved by applying adapted thermodynamic models taking into account the reservoir fluid composition obtained from the core extract altogether with the local pressure-temperature conditions.

\section{REFERENCES}

Abdoul, W., Rauzy, E. and Péneloux, A. (1991) Group Contribution Equation of State for Correlating and Predicting Thermodynamic Properties of Weakly Polar and Non-Associating Mixtures. Binary and Multi-Component Systems. Fluid Phase Equilibria, 69, 47-102. 
Calange, S. (1996) Modélisation thermodynamique compositionnelle de la cristallisation des bruts paraffiniques. PhD Thesis, université de Pau et des Pays de l'Adour.

Calange, S., Ruffier-Meray, V. and Béhar, E. (1997) Onset Crystallisation Temperature and Deposit Amount for Waxy Crudes: Experimental Determination and Thermodynamic Modelling. SPE 37239, International Symposium of Oil Field Chemistry, Houston TX, 283-290.

Carlson, R.M.K., Teerman, S.C., Moldowan, J.M., Jacobson, S.R., Chan, E.I., Dorrough, K.S., Seetoo, W.C. and Mertani, B. (1993) High Temperature Gas Chromatography of High Wax Oils. Indonesian Petroleum Association, 22nd Annual Convention Proceedings, Jakarta, Indonesia, 483-507.

Carnahan, N.F. (1989) Paraffin Deposition in Petroleum Production. J. Petrol. Technol., 41, 10, 1024-1025, 1106.

Del Rio, J.C., Philp, P. and Allen, J. (1992) Nature and Geochemistry of High Molecular Weight Hydrocarbons (above C40) in Oils and Solid Bitumens. Org. Geochem., 4, 541-553.

Dirand, M., Chevallier, V., Provost, E., Bouroukba, M. and Petitjean, D. (1998) Multicomponent Paraffin Waxes and Petroleum Solid Deposits: Structural and Thermodynamic State. Fuel, 77, 12, 1253-1260.

Ferworm, K. (1997) Control of Wax Deposition: an Experimental Investigation of Crystal Morphology and an Evaluation of Various Chemical Solvents. SPE 37240, International Symposium on Oil Field Chemistry, Houston, TX, 291-310.

Heath, D., Lewis, C. and Rowland, S. (1997) The Use of High Temperature Gas Chromatography to Study the Biodegradation of High Molecular Weight Hydrocarbons. Org. Geochem., 26, 769-786.

Mueller, E. and Philp, R.P. (1998) Extraction of High Molecular Weight Hydrocarbons from Source Rocks-An Example from the Green River Formation, Unita Basin, Utah. Org. Geochem., 28, 625-631.

Peng, D.Y. and Robinson, D.B. (1976) A New Two-Constant Equation of State. Ind. Eng. Chem. Fundam., 15, 59-64.

Philp, R.P. (1994) High Temperature Gas Chromatography for the Analysis of Fossil Fuels: A Review. J. of High Res. Chromato., 17, 398-406.

Philp, R.P., Bishop, A.N., Del Rio, J.C. and Allen, J. (1995) Characterisation of High Molecular Weight Hydrocarbons $\left(>\mathrm{C}_{40}\right)$ in Oils and Reservoirs Rocks. The Geochemistry of Reservoirs, Geological Society Special Publication, 86, 71-75.

Ruffier-Meray, V., Volle, J.L., Schranz, C.J.P., Le Maréchal, P. and Béhar, E. (1993) Influence of Light Ends on the Onset Crystallisation Temperature of Waxy Crude within the Frame of Multiphase Transport. SPE 26549, 68th Annual Technical Conference and Exhibition of SPE: Production Operations and Engineering, Houston, TX, 369-373.

Thanh, N.X., Hsieh, M. and Philp, R.P. (1999) Waxes and Asphaltenes in Crude Oils. Org. Geochem., 30, 119-132.

Weingarten, J.S. and Euchner, J.A. (1988) Methods for Predicting Wax Precipitation and Deposition. SPE Production Engineering, 3, 1, 121-126.

Final manuscript received in November 2001 